\title{
Potential of Pharmacodynamic Interaction for Hospital Patients with Stroke: A Retrospective Study
}

\author{
$1^{\text {st }}$ Ikhwan Yuda Kusuma \\ Departement of Pharmacy \\ Harapan Bangsa University \\ Banyumas, Indonesia \\ ikhwanyudakusuma@uhb.ac.id
}

\author{
$2^{\text {nd }}$ Desy Nawangsari \\ Departement of Pharmacy \\ Harapan Bangsa University \\ Banyumas, Indonesia \\ desynawangsari@uhb.ac.id \\ $4^{\text {th }}$ Yuyun Pujiarti \\ Departement of Pharmacy \\ Harapan Bangsa University \\ Banyumas, Indonesia
}

\author{
$3^{\text {rd }}$ Linda Sukiatno \\ Departement of Pharmacy \\ Harapan Bangsa University \\ Banyumas, Indonesia
}

\begin{abstract}
Stroke is a functional brain disorder in the form of nerve paralysis (deficit neurologic) due to obstruction of blood flow to the brain. Based on the Basic health research (Riskesdas) in 2018, the prevalence of stroke in Indonesia increased from $7 \%$ (2013) to $10.9 \%$ (2018) so it is necessary to optimize therapy for patients. Stroke treatment therapy, in general, uses two or more drugs (polypharmacy) so that this is able to increase the potential for drug interactions in patients either pharmacokinetic or pharmacodynamic. This study was aimed to investigate the potential for pharmacodynamic drug interactions and management of drug interaction events on stroke patients with polypharmacy therapy in hospital. The method of this study was retrospective observational. Data were analyzed descriptively using Stockley's Drug Interaction, Drug Interaction Facts, www.drugs.com database, and Medscape Drug Interactions Checker. The sampling technique employed in this study was total sampling method. The findings revealed that potential drug interactions on stroke patients in the hospital were $61.40 \% \quad(n=27$ samples $)$. The most mechanism pattern was pharmacodynamic interaction between aspirin-amlodipine $(\mathbf{1 3 . 8 \%})$ and the most severity was in moderate level $(\mathbf{7 7 . 7 8 \%})$.
\end{abstract}

Keywords: stroke, pharmacodynamics, drug interactions, hospital

\section{INTRODUCTION}

Stroke is a disease or functional disorder of the brain in the form of nerve paralysis (neurologic deficit) due to obstruction of blood flow to the brain, which consists of signs or symptoms of loss of nervous system function. Stroke can cause symptoms and cause and effect. The symptoms caused last more than 24 hours and cause death, in addition to causing stroke death will also have an impact on life [1].

The American Stroke Association 2018, states that in the United States around 795,000 people have a stroke each year, of which 610,000 have a stroke for the first time and 185,000 people have recurrent strokes. Of these more than 133,000 people die annually. The data shows that every 3 minutes 45 seconds one person dies from a stroke [2]. In Indonesia stroke occupies the third position after heart disease and cancer. As many as $28.5 \%$ of patients died and the rest suffered from partial or total paralysis. Only $15 \%$ can recover completely from stroke and disability[3] The prevalence of stroke in Indonesia based on the Indonesia Basic Health Research 2018 has increased from 7\% (2013) to $10.9 \%$ (2018) so that it is necessary to optimize therapy for patients.[4].

Factors that can cause a stroke are divided into risk factors that cannot be modified and risk factors that can be modified. Risk factors that cannot be modified include an increase in age and male sex. Modifiable risk factors include hypertension, diabetes mellitus, and dyslipidemia. Various types of risk factors for stroke must be resolved to improve quality and maintain patient life. However, the number of drugs used for therapy can also cause things that can not be avoided such as the possibility of treatment that is not in line with expectations. The use of many drugs is very risky to cause interactions between drugs even though all drug administration is clinically indicated [5].

Drug interactions are one of the factors that influence the body's response to treatment and are considered clinically important if they cause toxicity and / or reduce the effectiveness of the drugs that interact so that changes occur in the therapeutic effect. The mechanism of drug interactions can be divided into interactions that involve the pharmacokinetic aspects of the drug and interactions that affect the pharmacodynamic response of the drug [6]. The high incidence of drug interactions is related to the number of drugs consumed so research is needed to identify potential drug interactions, especially through pharmacodynamic mechanisms in stroke patients who are hospitalized. It is hoped that this research will be able to minimize drug prescription that causes drug interactions that can harm patients. 


\section{RESEARCH METHODS}

The design of this study is a descriptive study with cross sectional approach. The source of the research data was retrospective data collection obtained from the medical records of stroke patients who were hospitalized. Data obtained by a total sampling method of 27 patients. Medical records were taken on June 1-30, 2019. Before data collection, inclusion and exclusion criteria had to be determined. Inclusion criteria are characteristics that need to be fulfilled by each member of the population that can be taken as a sample while exclusion criteria are characteristics of population members that cannot be sampled [7]. Medical record sheets containing two quantities of drugs (prescriptions) will then be identified through the trusted literature Stockley's Drug Interaction, Drug Interaction Facts, www.drug.com data base and Medscape Drug Interactions Checker from the data then grouped based on the mechanism of pharmacodynamic interactions that occur.

\section{RESULTS AND DISCUSSION}

This research was conducted by retrospective method by directly looking at the observation sheet of stroke patients in the hospital inpatient installation on 1-30 June 2019 as many as 27 patients. Based on the inclusion and exclusion criteria in this study, the results of this study are as follows:

\section{A. Patient Characteristics Based on Gender}

Before being used for data retrieval, identification is done by looking at the gender on the patient's prescription.

TABLE I. CHARACTERISTICS OF STROKE PATIENTS BY

\begin{tabular}{llcc}
\hline \multirow{2}{*}{ Patient Characteristics } & $\begin{array}{c}\text { Number of } \\
\text { Patients }\end{array}$ & $\begin{array}{c}\text { Percentage } \\
(\boldsymbol{\%})\end{array}$ \\
\hline \multirow{2}{*}{ Gender } & Male & 17 & 62,96 \\
& Female & 10 & 37,04 \\
\hline Total & & 27 & 100 \\
\hline
\end{tabular}

From table I it can be seen that the characteristics of patients by gender, the prevalence of stroke in male $(62.96 \%)$ more than female $(37.04 \%)$. Certain stroke risk factors such as smoking and a history of alcohol consumption that are found in male are known to influence the occurrence of stroke. This shows that stroke affects more in male than female (Watila, 2011).

\section{B. Patient Characteristics Based on Age}

Furthermore, data collection is performed for identification by looking at the age of the patient's medical record.

\begin{tabular}{lccc}
\multicolumn{2}{l}{ TABLE II. CHARACTERISTICS OF STROKE PATIENTS BY AGE } \\
\hline \multirow{2}{*}{ Patient Characteristics } & $\begin{array}{c}\text { Number of } \\
\text { Patients }\end{array}$ & $\begin{array}{c}\text { Percentage } \\
(\mathbf{\%})\end{array}$ \\
\hline \multirow{2}{*}{ Age } & $41-50$ & 3 & 11,11 \\
& $51-60$ & 6 & 22,22 \\
& $61-70$ & 18 & 66,67 \\
\hline \multicolumn{2}{l}{ Total } & 27 & 100 \\
\hline
\end{tabular}

Table II showed that the majority of stroke patients aged $61-70$ years were $66.67 \%$ of patients, followed by ages 51-60 years (22.22\%), then aged $41-50$ years at $11.11 \%$. The increase in the frequency of strokes with increasing age is related to the aging process, in which all organs of the body experience deterioration in function, including the brain's blood vessels. The blood vessels become inelastic, especially the endothelial part that experiences thickening in the intima, resulting in narrowed lumen of the blood vessels and an impact on decreasing cerebral blood flow [9].

C. The Occurrence of Drug Interactions Based on the Number of Medical Records

Data is collected by identifying the sample based on the incidence of drug interactions.

TABLE III. POTENTIAL DRUG INTERACTIONS IN STROKE PATIENTS BASED ON THE NUMBER OF MEDICAL RECORDS WITH INTERACTING DRUGS

\begin{tabular}{lcc}
\hline \multicolumn{1}{c}{ Interaction Events } & $\begin{array}{c}\text { Number of } \\
\text { Medical Records }\end{array}$ & $\begin{array}{c}\text { Percentage } \\
(\boldsymbol{\%})\end{array}$ \\
\hline Interaction Occurs & 21 & 77,78 \\
No Interaction Occurs & 6 & 22,22 \\
\hline Total & 27 & 100 \\
\hline
\end{tabular}

Drug interactions on medical record data taken and identified using Stockleys, Tatro, and drug interactions.com. Based on observations on therapies received by 27 stroke patients, 21 patients have the potential for drug interactions with $77.78 \%$ interactions. Drug interactions observed in this study are potential drug interactions, that is interactions between drugs that may occur in patients after taking them. Identified drug interactions were 34 drug combinations. In the potential for drug interactions are divided into two components, according to the severity and mechanism of drug interactions. The results in this study can be said is the latest data for potential drug interactions in hospital inpatient installations.

From the table III data it is seen that the percentage of the number of medical records interacting was 21 medical records $(77.78 \%)$ and 6 medical records $(22.22 \%)$ did not experience drug interactions. So that it can be seen that the number of medical records that interact more than the number of medical records that do not occur drug interactions. The more drugs used by patients, the more likely it is to have drug interactions [10]

\section{Interaction Categories Based on Severity}

Data is collected by identifying samples based on interaction categories to determine the severity associated with the type and magnitude of the effect.

TABLE IV. PERCENTAGE OF DRUG INTERACTION CATEGORIES IN STROKE PATIENTS BASED ON SEVERITY

\begin{tabular}{lcc}
\multicolumn{2}{c}{ SEVERITY } & \\
\hline \multicolumn{1}{c}{ Severity } & $\begin{array}{c}\text { Number of } \\
\text { Interaction Types }\end{array}$ & Percentage (\%) \\
\hline Major & 3 & 8,33 \\
Moderate & 28 & 77,78 \\
Minor & 5 & 13,89 \\
\hline Total & 36 & 100 \\
\hline
\end{tabular}


From table IV it can be seen the percentage of interaction groups based on the severity that has been analyzed according to the mechanism of pharmacodynamic interactions, for the major categories are 3 drug interactions (8.33\%), minor 5 drug interactions (13.89\%) and moderate 28 incidence of drug interactions (77.78\%). Most drug interactions in this study were in the moderate category. Moderate interactions are clinically significant, usually avoiding combinations of drugs taken together and using them only in special circumstances. From this severity it can be concluded that the use of a combination of drugs in inpatient stroke patients needs to be considered again, because the moderate severity indicates that the drug has the potential to endanger the patient and some type of intervention / monitoring must be carried out[11] .

\section{E. Interaction Categories Based on Interaction Mechanisms}

Data collection types of drug interactions are carried out to determine the mechanism of drug interactions, so pharmacists can determine the appropriate steps in overcoming the problem.
TABLE V. PERCENTAGE OF DRUG INTERACTION CATEGORIES IN STROKE PATIENTS BASED ON INTERACTION MECHANISM

\begin{tabular}{ccc}
\hline $\begin{array}{c}\text { Interaction } \\
\text { Mechanism }\end{array}$ & $\begin{array}{c}\text { Number of } \\
\text { Interaction Types }\end{array}$ & $\begin{array}{c}\text { Percentage } \\
(\boldsymbol{\%})\end{array}$ \\
\hline Pharmacokinetics & 21 & 38.60 \\
Pharmacodynamics & 36 & 61,40 \\
\hline Total & 57 & 100 \\
\hline
\end{tabular}

Table $\mathrm{V}$ shows that the percentage of drug interactions with pharmacodynamic mechanisms is higher, with 36 types (61.40\%) compared to 21 types of drug interactions with pharmacokinetic mechanisms (38.60\%).

\section{F. Identification of Interactions Based on} Pharmacodynamic Interaction Mechanisms

Drug interactions that can be observed in this study are potential drug interactions, which are interactions between drugs that may occur in patients after taking them. Pharmacodynamic interactions are interactions that occur between drugs that have similar pharmacological effects, antagonistic effects, or side effects. This interaction can occur due to competition at the receptor or occurs between drugs that work on the same physiological system [13].

TABLE VI. IDENTIFICATION OF PHARMACODYNAMIC DRUG INTERACTIONS

\begin{tabular}{|c|c|c|c|c|c|}
\hline Drug A & Drug B & Severity & Interaction Effect & Number & $\begin{array}{c}\text { Percentage } \\
(\%)\end{array}$ \\
\hline Amitriptyline & Diazepam & Moderate & $\begin{array}{l}\text { Amitriptyline and diazepam cause a synergistic effect by increasing their } \\
\text { additive effects on the central nervous system [14]. }\end{array}$ & 1 & 2,77 \\
\hline Amitriptyline & Alprazolam & Moderate & $\begin{array}{l}\text { Amitriptyline and alprazolam cause synergistic effects by increasing their } \\
\text { additive effects on the central nervous system [14]. }\end{array}$ & 1 & 2,77 \\
\hline Amlodipine & Diklofenak & Moderate & Diclofenac antihypertensive effect of some calcium channel blockers [14]. & 1 & 2,77 \\
\hline Amlodipine & Captopril & Minor & Amlodipine inhibits calcium channels and the effects of captopril [14]. & 1 & 2,77 \\
\hline Aspirin & Amlodipine & Moderate & Aspilet can reduce antihypertensive effects [14]. & 5 & 13,8 \\
\hline Aspirin & Valsartan & Moderate & Aspilet can cause fluid retention, which also affects blood pressure [14]. & 1 & 2,77 \\
\hline Aspirin & Dexamethasone & Moderate & $\begin{array}{l}\text { Dexamethasone decreases serum concentration and the therapeutic effect of } \\
\text { salicylates [13]-[15] }\end{array}$ & 2 & 5,55 \\
\hline Aspirin & Insulin glargine & Moderate & $\begin{array}{l}\text { Aspirin increases the risk of hypoglycemia by increasing insulin secretion } \\
\text { [14]. }\end{array}$ & 1 & 2,77 \\
\hline Aspirin & Insulin aspart & Moderate & $\begin{array}{l}\text { Aspirin increases the risk of hypoglycemia by increasing insulin secretion } \\
\text { [14]. }\end{array}$ & 1 & 2,77 \\
\hline Aspirin & Clopidogrel & Moderate & $\begin{array}{l}\text { Clopidogrel inhibits platelet aggregation and increases the risk of } \\
\text { gastrointestinal bleeding [14], [15]. }\end{array}$ & 2 & 5,55 \\
\hline Aspirin & Insulin detemir & Moderate & $\begin{array}{l}\text { Clopidogrel inhibits platelet aggregation and increases the risk of } \\
\text { gastrointestinal bleeding [14], [15]. }\end{array}$ & 1 & 2,77 \\
\hline Aspirin & Nitroglyserin & Minor & $\begin{array}{l}\text { Aspirin increases serum concentration and increases the action of } \\
\text { nitroglycerin [13], [14]. }\end{array}$ & 2 & 5,55 \\
\hline Aspirin & Ketorolak & Major & Aspririn increases the risk of serious side effects related to ketorolac [14]. & 2 & 5,55 \\
\hline Aspirin & Candesartan & Moderate & Aspirin decreases antihypertensive effects and causes fluid retention [14]. & 2 & 5,55 \\
\hline Captopril & Ferro sulfat & Moderate & Ferro sulfate reduces the effects of captopril [13]. & 2 & 5,55 \\
\hline Dexamethasone & Insulin Aspart & Moderate & Dexamethasone causes hyperglycemia [14]. & 1 & 2,77 \\
\hline Fenofibrat & Insulin detemir & Moderate & $\begin{array}{l}\text { Phenofibrate increases the risk of hypoglycemia by increasing insulin } \\
\text { sensitivity [15]. }\end{array}$ & 1 & 2,77 \\
\hline Furosemide & Aspirin & Minor & Aspirin reduces the effects of fuurosemide $[14],[15]$. & 2 & 5,55 \\
\hline Ketorolak & Candesartan & Moderate & $\begin{array}{l}\text { Ketorolac decreases the antihypertensive effect and causes fluid retention } \\
{[14] \text {. }}\end{array}$ & 1 & 2,77 \\
\hline $\begin{array}{l}\text { Methyl } \\
\text { prednisolone }\end{array}$ & Amlodipine & Moderate & $\begin{array}{l}\text { Methylprednisolone can reduce the effects of antihypertensive drugs by } \\
\text { inducing sodium and fluid retention [14]. }\end{array}$ & 2 & 5,55 \\
\hline Phenytoin & Paracetamol & Moderate & $\begin{array}{l}\text { Phenytoin can increase the potential for acetaminophen hepatotoxicity and } \\
\text { reduce its pharmacological effects [14]. }\end{array}$ & 1 & 2,77 \\
\hline Simvastatin & Fenofibrat & Major & $\begin{array}{l}\text { Simvastatin increases the risk of musculoskeletal toxicity by inhibiting } \\
\text { HMG-CoA reductase [15] }\end{array}$ & 1 & 2,77 \\
\hline Warfarin & Paracetamol & Moderate & Paracetamol increases the antithrombotic effect of anticoagulants [13] & 2 & 5,55 \\
\hline \multicolumn{4}{|r|}{ Total } & 36 & 100 \\
\hline
\end{tabular}


From the description above it can be concluded that most of the stroke patients hospitalized have the potential to experience pharmacodynamic drug interactions. Identification of pharmacodynamic drug interactions can be seen in table VI.

One of the drugs used for stroke patients is antiplatelet. Antiplatelet is a drug that inhibits platelet aggregation so that it can inhibit thrombus formation in the arterial system. Based on table $\mathrm{V}$, an antiplatelet class of drugs that are often used is aspirin. Aspirin works to reduce platelet activity by inhibiting irreversible COX-1 (cyclooxygenase) to inhibit TXA2 production and cause a decrease in thromboxane synthesis, which thromboxane is needed to facilitate platelet aggregation and stimulate platelet activity [16].

Amlodipine is often used in stroke patients because it can reduce the incidence of recurrent strokes by $23 \%$. Amlodipine is a CCB (Calcium Chanel Blocker) group. Antihypertensive drugs from the $\mathrm{CCB}$ group in addition to lowering blood pressure, are also useful in preventing atherotrombotic type strokes in large arteries in the brain. $\mathrm{CCB}$ has been shown to provide better protection than beta blockers, diuretics, and ACEI [17].

Based on the severity, drug interactions are grouped into minor interactions (mild effects / can be handled well), moderate interactions (moderate effects / can cause organ damage), and major interactions (fatal effects / can cause death) [13].

Table VI shows that the most common pharmacodynamic drug interaki is the interaction of aspirin and amlodipine with moderate severity, which shows the highest rate, at $13.8 \%$. The use of aspirin and amlodipine together can reduce the antihypertensive effect of some calcium channel blockers. This mechanism is related to changes in vascular tone, which are dependent on prostacyclin and other vasodilatory prostanoids. When aspirin is added to a patient's regimen that already uses amlodipine, it causes an increase in blood pressure. The necessary management is to monitor blood pressure [14].

In addition, it is known that there is a potential for major / serious interactions between aspirin and ketorolac in $2(5.5 \%)$ occurrences of drug interactions. The use of aspirin and ketorolac together can increase the risk of serious side effects of ketorolac, including kidney failure and gastrointestinal inflammation, bleeding, ulceration, and perforation [14]. This mechanism occurs because aspirin can replace ketorolac as a binding protein so that it can potentially have side effects of synergism [13]. The management needed is monitoring the use of ketorolac together with aspirin which is considered a contraindication so that it should not be used simultaneously [14].

The least drug interactions are amlodipine and captopril. The use of amlodipine and captopril together can increase the hypotensive additive effect. The mechanism of this effect is amlodipine inhibits calcium channels and the effects of captopril. The management needed is monitoring systemic blood pressure during the administration of this drug simultaneously, especially during the first one to three weeks of therapy [14].

\section{CONCLUSION}

The results showed that of the 27 stroke patients, there were $61.40 \%$ incidence of pharmacodynamic interaction mechanisms. The most mechanism pattern is pharmacodynamic interaction between aspirin-amlodipine $(13.8 \%)$ and the severity with the most occurrence is moderate $(77.78 \%)$.

\section{REFERENCES}

[1] I. Junaidi, Stroke Waspadai Ancamannya. Yogyakarta: Andi Offset, 2011.

[2] C. A. Benjamin EJ, Virani SS, Callaway CW, "Heart Disease and Stroke Statistics 2018 At-a-Glance," 2018.

[3] N. dan F. Khairunnisa, "HEMIPARESE SINISTRA, PARESE NERVUS VII, IX, X, XII e.c STROKE NONHEMORRHAGIC," vol. 2, no. 3, pp. 52-59, 2014.

[4] Kemenkes, "Riskesdas 2018."

[5] Y. . Terrie, "Understanding and Managing Polypharmacy in the Elderly," 2004.

[6] K. Baxter, "Stockley's Drug Interactions Eighth Edition," 2008.

[7] S. Notoatmodjo, "Metodologi Penelitian Kesehatan.” 2010.

[8] A. Watila, M. M., Nyandaiti, Y. W., Bwala, S. A., \& Ibrahim, "Gender variation in risk factors and clinical presentation of acute stroke, Northeastern Nigeria,” vol. 3(March), 2011.

[9] S. P. D. I. T. S. H. Kristiyawati, "Faktor Risiko yang Berhubungan dengan Kejadian Stroke di Rumah Sakit Panti Wilasa Citarum Semarang.” 2009.

[10] R. S. Mendes-netto, C. Q. V Silva, A. D. O. Filho, C. E. Rocha, and D. P. Lyra-junior, "Assessment of drug interactions in elderly patients of a family health care unit in Aracaju (Brazil): A pilot study," vol. 5, no. July, pp. 812-818, 2011.

[11] \& F. Barliana, M. I., Sari, D. R., “Analisis Potensi Interaksi Obat dan Manifestasi Klinik Resep Anak di Apotek Bandung.," $J$. Farm. Klin. Indones., vol. (3), 121-1, 2013.

[12] M. I. Barliana, D. R. Sari, and M. Faturrahman, “Analisis Potensi Interaksi Obat dan Manifestasi Klinik Resep Anak di Apotek Bandung," J. Farm. Klin. Indones., vol. 2, no. 3, pp. 121-126, 2013.

[13] D. S. Tatro, Drug Interaction Facts. A Wolters Kluwer Company, 2009.

[14] Drugs.com., drug interactions checker. 2019.

[15] K. Baxter, Stockley 's Drug Interactions Pocket Companion. 2010.

[16] C. A. Dinata, Y. Safrita, and S. Sastri, "Artikel Penelitian Gambaran Faktor Risiko dan Tipe Stroke pada Pasien Rawat Inap di Bagian Penyakit Dalam RSUD Kabupaten Solok Selatan Periode 1 Januari 2010 - 31 Juni 2012," vol. 2, no. 2, pp. 57-61, 2013.

[17] R. Ravenni, J. F. Jabre, E. Casiglia, A. Mazza, M. Hospital, and M. Hospital, "Primary stroke prevention and hypertension treatment: which is the first-line strategy?," vol. 3, 2011. 